\title{
Pengembangan Bahan Ajar Berbasis Konteks dan Kreativitas untuk Melatihkan Literasi Sains Siswa Sekolah Dasar
}

\author{
Sistiana Windyariani ${ }^{1}$, Setiono ${ }^{3}$, Astri Sutisnawati ${ }^{2)}$, \\ I, 2, Progam Studi Pendidikan Biologi, FKIP, Universitas Muhammadiyah Sukabumi \\ 3, Program Studi Pendidikan Guru Sekolah Dasar FKIP, Universitas Muhammadiyah Sukabumi \\ Jln. R. Syamsudin SH No 50 Sukabumi, Jawa Barat Indonesia. \\ surat elektronik: windyariani@gmail.com
}

\begin{abstract}
ABSTRAK
Tujuan penelitian ini mengembangkan bahan ajar berbasis konteks dan kreativitas untuk meningkatkan literasi sains siswa Sekolah Dasar. Penelitian ini merupakan penelitian R \& D (Penelitian dan Pengembangan) yang meliputi tiga tahap penelitian yaitu: I) Studi Pendahuluan, 2) Pengembangan bahan ajar, dan 3) Uji coba bahan ajar. Studi pendahuluan dilakukan dengan studi kurikulum IPA di SD dan survey lapangan terhadap guru-guru kelas 4 dan 5 SD di kota sukabumi sebanyak I6 orang. Pengembangan model berupa penyusunan bahan ajar serta validasi oleh expert judgement dan peer reviewer. Uji coba terbatas dan uji coba lebih luas bahan ajar. Tanggapan dari guru dilakukan dengan memberikan kuosioner kepada 3 orang guru. Hasil yang diperoleh dari penelitian ini adalah, berdasarkan analisis kurikulum pembelajaran IPA di SD menuntut adanya pembelajaran kontekstual yang terintegrasi dengan praktikum untuk menanamkan konsep/konten yang selaras dengan kemampuan literasi sains, 2) telah dihasilkan 3 buah bahan ajar dengan konteks: a) Kemanakah Perginya Capung?, b) Mengapa Hujan Turun?, c) Mengapa gigi kita bisa sakit?. 3) Hasil uji coba terbatas dan lebih luas dijadikan pijakan untuk pengembangan bahan ajar, 4) Umumnya guru memberikan respon yang baik terhadap bahan ajar yang telah dikembangkan.
\end{abstract}

Kata kunci: Bahan ajar berbasis konteks dan kreativitas, kemampuan literasi sains.

\section{Pendahuluan}

Perolehan Siswa Indonesia pada hasil studi PISA (Programme for International Student Assessment) berada pada peringkat ke 64 dari 65 negara dengan skor rata-rata 375 , sedangkan skor rata-rata internasional 500 (OECD, 2013). Hal ini menunjukkan lemahnya kemampuan literasi sains siswa Indonesia, padahal kemampuan ini merupakan elemen penting dalam pendidikan sains teknologi masyarakat modern, serta sangat krusial bagi seluruh warganegara bukan hanya untuk yang belajar atau berkarir di sains (Phearson, 2008).

Literasi sains merupakan kemampuan mengimplementasikan pengetahuan yang dimiliki siswa untuk menyelesaikan masalah-masalah di kehidupan nyata. (Rustaman, 2004; Toharudin, 20II). Semakin hari masalah di dunia yang berkaitan dengan sains dan teknologi semakin banyak dan setiap anggota masyarakat dituntut untuk mampu ikut aktif berdiskusi dan terlibat dalam proses pengambilan keputusan untuk menyelesaikan masalah.

Siswa perlu mengetahui relevansi dari sebuah pengajaran, seperti pada kehidupan sehari-hari atau relevansinya pada kehidupan bermasyarakat. Dengan demikian pendidikan sains diharapkan dapat membimbing siswa untuk mencapai cita-citanya dalam pendidikan melalui sains. Hal ini penting bagi siswa untuk dapat lebih menghargai sains dalam pendidikan mereka (Holbrook, 2005).

Noris dan Philips (2003) dalam hasil penelitiannya mengemukakan bahwa, untuk meningkatkan literasi sains guru harus kreatif mengembangkan pertanyaan berbasis masalah. Berdasarkan temuan tersebut, dalam pembelajaran sains perlu memunculkan tahapan yang memungkinkan siswa untuk memecahkan masalah berdasarkan konteks masalah di kehidupan sehari-hari, kemudian melaksanakan eksperimen atau praktikum untuk membentuk konsep dan mengembangkannya untuk diterapkan pada konsep yang baru yang memungkinkan terjadinya scaffolding untuk belajar sains serta berargumentasi.

Pada pembelajaran berbasis konteks, konteks digunakan sebagai titik awal untuk mengembangkan pemikiran ilmiah (Bennett, Lubben \& Hogarth, 2006; Ramsden, 1997). Tujuan utama dari pendekatan berbasis konteks adalah untuk menyajikan konsep ilmiah untuk siswa melalui kegiatan di kehidupan sehari-hari yang dipilih, yang mampu meningkatkan motivasi mereka sehingga tertarik untuk belajar sains (Barker dan Millar, 1999; Kose dan Tosun, 201I). Selama membentuk konteks dalam melakukan ekperimen pada umumnya siswa menggunakan bahan-bahan yang mudah digunakan dan tersedia di rumah. 
Kemampuan kreatif diperlukan dalam memecahkan masalah, karena dalam mencari pemecahan masalah perlu menggunakan pengetahuan yang telah diketahui dalam situasi baru yang belum dikenal. Pencapaian siswa dalam pembelajaran sains tidak hanya menguasai pemahaman konsep dan keterampilan proses, melainkan juga bagaimana mereka berpikir kreatif. Pencapaian perkembangan tersebut dapat difasilitasi dengan cara memberikan tantangan yang menekankan pada proses pemecahan masalah (Suratno, 2009). Menurut Knapp and Schell (200I) belajar dalam konteks yang banyak memberikan siswa pengalaman menggunakan apa yang dipelajari mengidentifikasi dan menyelesaikan permasalahan pada konteks-konteks yang baru.

Konteks dan kreativitas dapat dimunculkan dan dilatihkan pada siswa melalui bahan ajar. Bahan ajar dapat memuat permasalahan dalam konteks kehidupan sehari-hari serta menuntut siswa untuk melakukan eksperimen dan atau penyajian data secara kreatif. Bahan ajar juga dapat dibuat dengan mengintegrasikan dimensi literasi sains, memuat tugas atau kegiatan, menyajikan ilustrasi atau gambar yang menarik (Wulan, 2010).

Penelitian ini dilakukan di level sekolah Dasar (SD), karena SD merupakan tempat formal pertama kali siswa mendapatkan pembelajaran sains. SD merupakan tahap pendidikan yang tepat bagi siswa untuk belajar sains agar memiliki konsep sains yang kuat di usia dini.

Kondisi yang ada saat ini menunjukkan bahwa tradisi pembelajaran sains di SD cenderung lebih berorientasi pada transfer pengetahuan serta konteks yang tidak relevan dengan kehidupan sehari-hari (Aikenhead, 2006). Menurut teori perkembangan Piaget, pada tahap SD anak sudah mampu mengembangkan pemikiran logis yang dapat diterapkan untuk memecahkan persoalan konkret yang dihadapi, namun sulit jika dihadapkan pada materi yang abstrak.

Berdasarkan latarbelakang yang telah dikemukakan maka masalah pada penelitian ini adalah: "Bagaimanakah bahan ajar berbasis konteks dan kreativitas untuk melatihkan literasi sains siswa sekolah dasar?”.

\section{Metode Penelitian}

Penelitian ini menggunakan model penelitian dan pengembangan pendidikan (educational research and development) hasil modifikasi dari metode penelitian R\&D Borg and Gall yang meliputi tahapan: I) Studi Pendahuluan, 2) Pengembangan Model, dan ke 3) Uji Model (Sukmadinata, 2005). Penelitian ini dilaksanakan selama dua tahun, hasil yang dipaparkan merupakan hasil penelitian tahun pertama sementara uji produk dan sosialisasi hasil akan dilaksanakan pada tahun kedua. Studi pendahuluan dilakukan dengan studi pustaka berupa analisis kurikulum mata pelajaran IPA SD, analisis kemampuan siswa SD pada konten dan konteks yang sesuai, serta studi literatur krativitas dan literasi sains. Studi lapangan dilaksanakan dengan cara mewawancarai 16 orang guru SD pada bulan Mei-Juni
2016. Hal-hal yang ditanyakan menyangkut pembelajaran IPA SD (praktikum, kesulitan dan kendala dalam pembelajaran IPA, serta literasi sains.

Pengembangan bahan ajar disusun menurut Wulan (2010) yang didalamnya mengemukakan kompetensi dasar, isi bahan ajar merupakan integrasi dari ketiga dimensi literasi sains (dimensi konten, konteks, dan proses), memuat tugas-tugas atau kegiatan, menyajikan ilustrasi atau gambar, dan mencantumkan sumber/literatur/kepustakaan.

Tahapan penyusunan bahan ajar dilakukan melalui proses (Anwar, 2010): a) Seleksi, yakni pengumpulan bahan ajar dari berbagai sumber dan menyesuaikan dengan kurikulum yang saat ini sedang digunakan yaitu kurikulum 2013. Bahan ajar yang disusun mencakup kepada 3 seri, yakni: I) Seri hewan dan tumbuhan (kelas 4), 2) Seri iklim (kelas 5), dan 3) Seri kesehatan (kelas 5). Bahan ajar dimulai dari judul berupa pertanyaan yang harus siswa jawab di akhir praktikum. b) Strukturisasi, yakni pemetaan konsep-konsep bahan ajar yang disusun secara terstruktur dan sistematis dalam satu pokok bahasan, c) Karakterisasi, bahan ajar dianalisis setiap konsep, ditentukan mana yang lebih sederhana, dekat dengan kehidupan siswa, konkret, kemudian perlahanlahan tingkat kesulitannya ditingkatkan, d) Reduksi, dengan cara pengabaian (mengabaikan hal yang dianggap rumit dengan pemikiran yang lebih mudah dipahami), penggunaan penjelasan berupa gambar, simbol, sketsa dan percobaan, serta penggunaan analogi yakni mengubah hal yang bersifat abstrak menjadi relatif lebih konkret.

Pengembangan bahan ajar berdasarkan analisis dari Standar Kompetensi dan Kompetensi dasar kurikulum 2013 sehingga diperoleh indikator di kelas 4 dan 5 sebagai berikut:

Tabel I. Analisis Kurikulum kelas 4 yang dipilih untuk seri

\begin{tabular}{llc}
\multicolumn{1}{c}{ KI } & \multicolumn{1}{c}{ KD } & Indikator \\
\hline 3. Memahami & 3.2. & 3.2.I Mendeskripsikan \\
pengetahuan & Mendeskripsikan & beberapa jenis \\
faktual dengan & daur hidup & hewan \\
cara & beberapa jenis & berdasarkan \\
mengamati & makhluk hidup & cirinya \\
dan menanya & & 3.2.2 Membandingkan \\
berdasarkan & & cara berkembang \\
rasa ingin tahu & & biak beberapa \\
tentang & & jenis hewan \\
dirinya, & & 3.2.3 Memberikan \\
makhluk & & contoh daur \\
ciptaan Tuhan & & hidup hewan \\
dan & 4.I. Menuliskan & 4.I.I Melakukan \\
kegiatannya, & hasil pengamatan & penyelidikan \\
benda-benda & tentang bentuk & tentang bagian \\
yang & luar (morfologi) & hewan \\
dijumpainya & tubuh hewan & 4.I.2 Menuliskan hasil \\
di rumah, di & dan tumbuhan & penyelidikan \\
sekolah, dan & serta fungsinya & tentang bagian \\
tempat & & hewan \\
bermain & 4.2. Menyajikan & 4.2.I Menyajikan hasil \\
& secara tertulis & penyelidikan \\
\hline
\end{tabular}




$\begin{array}{ll}\text { hasil pengamatan } & \text { mengenai daur } \\ \text { daur hidup } & \text { hidup beberapa } \\ \text { beberapa hewan } & \text { hewan (capung, } \\ & \text { kupu-kupu, dan } \\ & \text { katak) dalam } \\ & \text { bentuk laporan } \\ & \text { sederhana } \\ 4.2 .2 \text { Mengusulkan } \\ \text { cara melestarikan } \\ \text { hewan }\end{array}$

Tabel 2. Analisis Kurikulum Kelas 5 untuk materi hujan dan kesehatan

\begin{tabular}{lll}
\hline \multicolumn{1}{c}{ KI } & \multicolumn{1}{c}{ KD } & \multicolumn{1}{c}{ Indikator } \\
\hline 3. Memahami & 3.5 & 3.5.I. \\
pengetahuan faktual & Mendeskripsika & Menjelaskan \\
dan konseptual & n siklus air dan & proses \\
dengan cara & dampaknya & terjadinya \\
mengamati dan & pada peristiwa & hujan \\
mencoba [mendengar, & di bumi serta & 3.5.2. \\
melihat, membaca] & kelangsungan & Menggambar \\
serta menanya & mahluk hidup & kan siklus \\
berdasarkan rasa ingin & & hujan \\
tahu secara kritis & 3.2 Mengenal & 3.2.I. \\
tentang dirinya, & organ tubuh & Mendeskripsi \\
makhluk ciptaan & manusia dan & kan fungsi \\
Tuhan dan & hewan serta & gigi \\
kegiatannya, dan & mendeskripsi- & \\
benda-benda yang & kan fungsinya & \\
dijumpainya di & 4.7 Menyajikan & 4.7.I. \\
rumah, sekolah, dan & laporan tentang & Melakukan \\
tempat bermain & jenis penyakit & praktikum \\
& yang & sederhana \\
& berhubungan & tentang gigi \\
& dengan & 4.7 .2$. \\
& gangguan pada & Mengusulkan \\
& organ tubuh & cara menjaga \\
& manusia & gigi \\
\hline & & \\
& &
\end{tabular}

Selanjutnya dilakukan expert judgement untuk menilai keterbacaan, kesesuaian konsep dan kesesuaian dengan siswa kelas 4 dan $5 \mathrm{SD}$, serta tampilan tampilan. Dilakukan juga penilaian bahan ajar oleh peer reviewer sebanyak 2 orang. Selanjutnya dilakukan Uji coba terbatas untuk menguji realiabilitas alat ukur penilaian dengan dengan melakukan uji coba kepada siswa pada satu sekolah, dan uji coba lebih luas pada dua sekolah. Wawancara terhadap guru dilakukan juga untuk menjaring tanggapan guru terhadap bahan ajar yang digunakan. Peneliti juga melengkapi hasil penelitian dengan catatan lapangan (anecdotal record) untuk menjaring hal-hal yang terjadi selama dilaksanakannya uji coba terbatas dan luas.

\section{Hasil dan Pembahasan}

Hasil dari penelitian ini adalah dihasilkannya bahan ajar dari 3 seri masing-masing untuk satu konteks, yang disajikan pada tabel 3 berikut:
Tabel 3. Bahan ajar yang dihasilkan

\begin{tabular}{lll}
\hline \multicolumn{1}{c}{ KD } & \multicolumn{1}{c}{ Seri } & \multicolumn{1}{c}{ Konteks (sebagai judul) } \\
\hline $\begin{array}{l}\text { Kelas 4. } \\
\text { 3. 2, 4.I, 4.2 }\end{array}$ & Hewan & $\begin{array}{l}\text { Kemanakah Perginya } \\
\text { Capung? }\end{array}$ \\
\hline $\begin{array}{l}\text { Kelas 5. } \\
\text { 3.5 }\end{array}$ & Iklim & Mengapa hujan turun? \\
\hline Kelas 5 & Kesehatan & $\begin{array}{l}\text { Mengapa kita bisa sakit } \\
\text { gigi? }\end{array}$ \\
\hline
\end{tabular}

Pada tabel 3, konteks yang berupa pertanyaan digunakan sebagai judul bahan ajar. Bahan ajar dalam penelitian ini mencakup pada pengetahuan, keterampilan, dan sikap yang telah disesuaikan dengan tuntutan literasi sains.

Penentuan judul merupakan salah satu tahap pada proses seleksi. Konteks didapatkan dari hasil identifikasi kurikulum terutama Kompetensi inti dan Kompetensi Dasar kurikulum 2013. Identifikasi penting untuk dilaksanakan untuk membantu pencapaian indikator pembelajaran. Konteks yang dipilih juga menyesuaikan dengan konteks aplikasi sains pada PISA. Menurut Rustaman et al., (2004) situasi nyata yang menjadi konteks aplikasi sains dalam PISA tidak secara khusus diangkat dari materi yang dipelajari di sekolah, melainkan diangkat dari kehidupan sehari-hari.

Proses seleksi juga dilakukan dengan cara memilih sumber bahan ajar. Sumber bahan ajar yang digunakan pada bahan ajar berbasis konteks adalah buku teks, buku kurikulum, internet, serta fenomena pada lingkungan alam. Menurut Depdiknas (2002) terdapat kriteria dalam melakukan proses seleksi agar penyesuaian kompetensi inti dan Kompetensi Dasar tidak meluas dan melebar. Kriteria yang dimaksud adalah I) Sahih (valid), materi yang dipilih telah dipastikan teruji kebenaran dan kesahihannya, 2) Tingkat kepentingan, materi yang dipilih penting untuk dipelajari, 3) Kebermanfaatan diupayakan dalam hal akademis dan non akademis.

Tahap selanjutnya adalah strukturisasi, berdasarkan sumber yang telah terkumpul selanjutnya dilakukan proses strukturisasi, berupa pemetaan konsep-konsep bahan ajar yang disusun secara terstruktur dan sistematis dalam satu pokok bahasan. Hal yang dilakukan adalah menentukan proposisi mikro dari sumber ajar yang telah diseleksi. Beberapa proposisi mikro yang senada kemudian disatukan menjadi proposisi makro. Proposisi makro dan mikro kemudian dibentuk menjadi struktur makro.

Tahapan selanjutnya dilakukan tahap karakterisasi. Pada tahap ini bahan ajar yang disusun dianalisis setiap konsep. Selanjutnya ditentukan mana yang lebih sederhana, yang lebih dekat dengan kehidupan siswa, yang kongkret, kemudian perlahan-lahan tingkat kesulitannya ditingkatkan dengan maksud agar motivasi siswa dibangun pada saat mempelajari bahan ajar.

Tahapan selanjutnya adalah reduksi. Tahapan ini menurut Anwar 2010, disebut dengan tahapan reduksi didaktik yakni: I) kembali pada tahap kualitatif, yakni eksplanasi akan lebih mudah jika disajikan dalam bentuk 
kata-kata (kualitatif) dibandingkan dalam bentuk angka (kuantitatif). 2) pengabaian, yakni mengabaikan hal yang dianggap rumit dengan pemikiran yang lebih mudah difahami, 3) penggunaan penjelasan berupa gambar, simbol, sketsa, dan percobaan. 4) penggunaan analogi, yakni mengubah hal-hal yang bersifat abstrak menjadi relatif lebih konkret.

Sebelum diujicobakan bahan ajar dijudgement terlebih dahulu oleh expert judgement dan hasilnya menunjukkan ketiga bahan ajar layak untuk digunakan dari aspek kelayakan komponen penyajian, kelayakan komponen bahasa dan kelayakan komponen isi. Selain oleh expert bahan ajar juga di judgement oleh dua orang peer reviewer. Adapun hasil penilaian dari peer reviewer (teman sejawat) ditampilkan pada tabel 4 berikut.

Tabel 4. Hasil penilaian Peer Reviewer terhadap bahan ajar

\begin{tabular}{|c|c|c|c|}
\hline $\begin{array}{l}\text { Konteks } \\
\text { (sebagai } \\
\text { judul) }\end{array}$ & Aspek & $\begin{array}{l}\text { Rata- } \\
\text { rata }\end{array}$ & Kesimpulan \\
\hline \multirow{7}{*}{$\begin{array}{l}\text { Kemanakah } \\
\text { Perginya } \\
\text { Capung? }\end{array}$} & $\overline{\text { Kelayakan }}$ & 93.75 & layak \\
\hline & komponen & & \\
\hline & penyajian & & \\
\hline & Kelayakan & 90.62 & layak \\
\hline & komponen bahasa & & \\
\hline & Kelayakan & 97.22 & layak \\
\hline & komponen isi & & \\
\hline \multirow{6}{*}{$\begin{array}{l}\text { Mengapa } \\
\text { hujan turun? }\end{array}$} & Kelayakan & $85.7 \mathrm{I}$ & layak \\
\hline & penyajian & & \\
\hline & Kelayakan & 89.44 & layak \\
\hline & komponen bahasa & & \\
\hline & Kelayakan & 82.13 & layak \\
\hline & komponen isi & & \\
\hline \multirow{6}{*}{$\begin{array}{l}\text { Mengapa } \\
\text { kita bisa } \\
\text { sakit gigi? }\end{array}$} & Kelayakan & 80.26 & layak \\
\hline & komponen & & \\
\hline & penyajian & & \\
\hline & Kelayakan & 83.43 & layak \\
\hline & komponen bahasa & & \\
\hline & $\begin{array}{l}\text { Kelayakan } \\
\text { komponen isi }\end{array}$ & $87.2 \mathrm{I}$ & layak \\
\hline
\end{tabular}

Tabel 4 menunjukkan penilaian dari dua orang peer reviewer yang menunjukkan bahan ajar layak untuk digunakan dalam aspek I) kelayakan komponen penyajian (yang meliputi, desain bahan ajar, kesesuaian gambar, kejelasan tulisan, dan kegiatan relevan), 2) Kelayakan komponen bahasa (yang meliputi, penggunaan bahasa baku, bahasa komunikatif, bahasa sesuai dengan karakter siswa SD dan konsistensi istilah), 3) Kelayakan komponen penyajian (yang meliputi, judul yang menimbulkan rasa ingin tahu, materi sesuai $\mathrm{KD}$, materi kontekstual dan menarik, kegiatan praktikum menarik, kegiatan praktikum melatihkan literasi sains, dan melatih kreativitas). Menurut Toharudin (20II), bahan ajar harus memiliki kriteria layak, berkesesuaian dengan kurikulum, menarik minat siswa, menumbuhkan motivasi dan menstimulasi aktivitas siswa, menyajikan gambar, komunikatif, logis dan sistematis, kontekstual. Berdasarkan hasil penilaian yang tercantum pada tabel 4 bahan ajar yang disusun telah memenuhi kriteria bahan ajar yang baik.

Selain telah berkesesuaian dengan kriteria, dan konteks sains, bahan ajar juga telah berkesuaian dengan aspek proses sains menurut PISA, yakni mengidentifikasi pertanyaan ilmiah, menjelaskan fenomena secara ilmiah, dan menggunakan bukti ilmiah (OECD, 2006; OECD, 2009). Kompetensi ini membutuhkan adanya demonstrasi yang dilakukan oleh siswa, dan memunculkan kemampuan pengetahuan dan kognitif, selain itu sikap, nilai, dan motivasi juga dapat terlihat pada saat mereka mendapatkan dan memberikan respon terhadap masalah yang terkait dengan sains.

Pada bahan ajar juga termuat Lembar Kerja Siswa yang berisi arahan kegiatan sederhana menggunakan bahan yang mudah ditemui namun mampu membantu siswa mengkonstruk pengetahuan terkait dengan permasalahan di awal. Berikut merupakan tampilan bahan ajar dari salah satu konteks mengapa hujan turun.
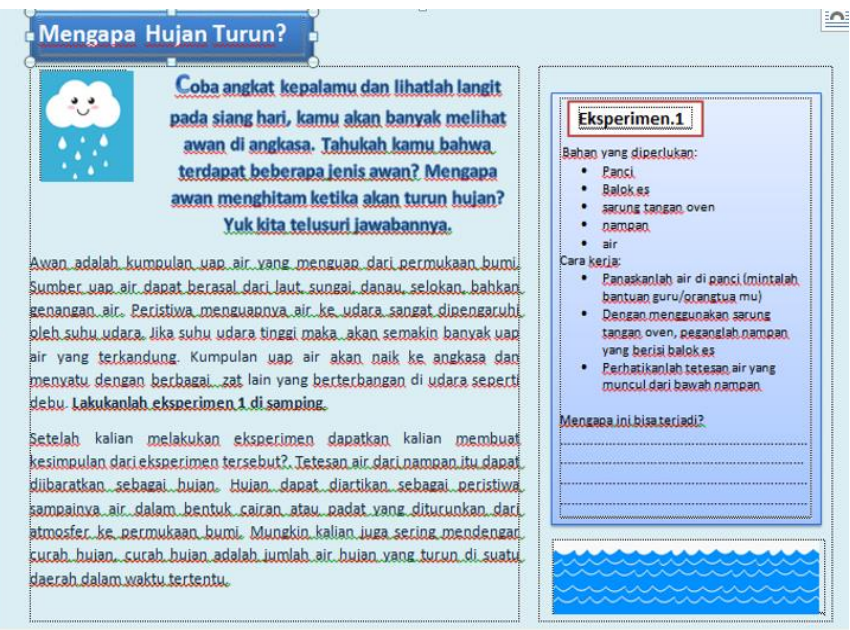

Gambar 2. Tampilan halaman pertama bahan ajar pada konteks hujan

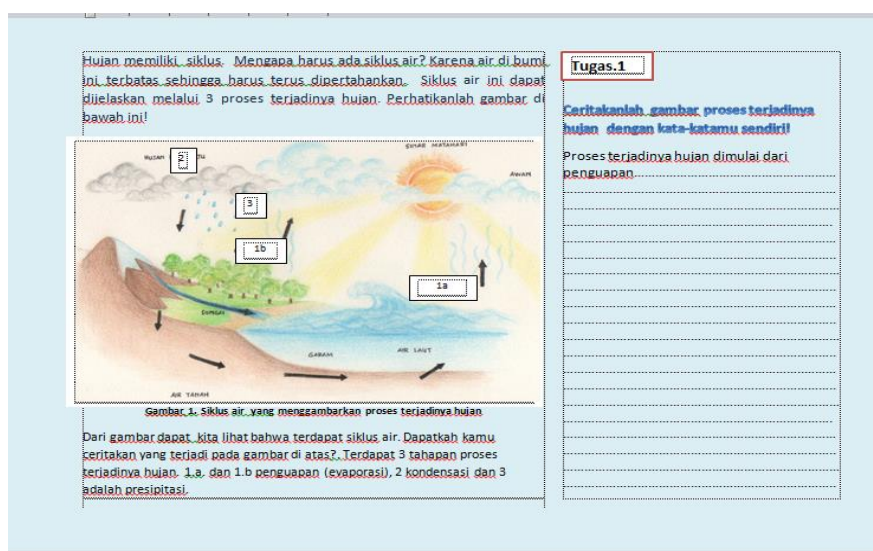

Gambar 3. Tampilan gambar pada bahan ajar

Kegiatan yang termuat pada bahan ajar berupa kegiatan yang membantu siswa untuk meningkatkan pemahaman. Menurut (Wulan. 2010). Tugas atau kegiatan yang dikerjakan siswa untuk melatihkan literasi sains menuntut siswa untuk mengintegrasikan konten, proses, dan konteks dalam satu kesatuan. Dimensi 
konten, proses, dan konteks disajikan secara terintegrasi dalam satu kesatuan di bahan ajar.

Bahan ajar yang telah disusun selanjutnya di ujicobakan secara terbatas dan secara luas. Hasil ujicoba terbatas dan luas ditunjukkan pada tabel 5 berikut:

Tabel 5. Tabel Ketuntasan Literasi Sains Uji Coba Terbatas dan Luas

\begin{tabular}{lllcl}
\hline $\begin{array}{l}\text { Konteks (sebagai } \\
\text { judul) }\end{array}$ & Uji coba & $\begin{array}{c}\text { Jumlah } \\
\text { siswa }\end{array}$ & Tuntas & $\begin{array}{l}\text { Tidak } \\
\text { Tuntas }\end{array}$ \\
\hline Kemanakah & terbatas & I8 & I2 & 6 \\
Perginya Capung? & luas & 73 & 68 & 5 \\
Mengapa hujan & terbatas & I9 & I2 & 7 \\
turun? & luas & 85 & 79 & 6 \\
Mengapa kita bisa & luas & 23 & I5 & 8 \\
sakit gigi? & terbatas & 64 & 59 & 5 \\
\hline
\end{tabular}

Dalam penelitian ini diperoleh nilai ketuntasan yang dilakukan melalui kegiatan posttest menggunakan soal literasi sains. Temuan yang didapatkan dari hasil uji coba terbatas dan luas beserta pengembangannya dirangkum pada tabel 5 berikut ini.

Tabel 6. Pengembangan Bahan ajar secara umum pada ketiga konteks

\begin{tabular}{|c|c|c|c|}
\hline Aspek & Awal & $\begin{array}{l}\text { Pengembangan } \\
\text { hasil uji coba } \\
\text { terbatas }\end{array}$ & $\begin{array}{c}\text { Pengembangan } \\
\text { hasil uji coba } \\
\text { lebih luas }\end{array}$ \\
\hline $\begin{array}{l}\text { KD dan } \\
\text { Indikat } \\
\text { or }\end{array}$ & $\begin{array}{c}\text { Tidak } \\
\text { dicantumkan }\end{array}$ & dicantumkan & dicantumkan \\
\hline $\begin{array}{l}\text { Tugas/ } \\
\text { kegiatan }\end{array}$ & $\begin{array}{c}\text { Tidak } \\
\text { mencantukan } \\
\text { tujuan, } \\
\text { belum } \\
\text { berupa tugas } \\
\text { untuk } \\
\text { memecahkan } \\
\text { masalah }\end{array}$ & $\begin{array}{c}\text { Mencantumka } \\
\mathrm{n} \text { tujuan, tugas } \\
\text { belum mencari } \\
\text { dan mengolah } \\
\text { informasi } \\
\text { sendiri }\end{array}$ & $\begin{array}{c}\text { Mencantumkan } \\
\text { tujuan, disertai } \\
\text { pertanyaan } \\
\text { pengarah, telah } \\
\text { menuntut siswa } \\
\text { mengintegrasi } \\
\text { dimensi literasi } \\
\text { sains }\end{array}$ \\
\hline $\begin{array}{l}\text { Aspek } \\
\text { literasi } \\
\text { sains }\end{array}$ & $\begin{array}{c}\text { Tidak } \\
\text { terintegrasi }\end{array}$ & $\begin{array}{l}\text { Aspek literasi } \\
\text { sains } \\
\text { terintegrasi } \\
\text { dalam masalah } \\
\text { yang } \\
\text { kontekstual }\end{array}$ & $\begin{array}{c}\text { Dikembangkan } \\
\text { kemampuan } \\
\text { untuk } \\
\text { memecahkan } \\
\text { masalah }\end{array}$ \\
\hline Gambar & $\begin{array}{c}\text { Kurang } \\
\text { menarik, } \\
\text { tidak } \\
\text { mencantumk } \\
\text { an sumber }\end{array}$ & $\begin{array}{c}\text { Menarik, } \\
\text { mencantumkan } \\
\text { sumber }\end{array}$ & $\begin{array}{c}\text { Menarik, } \\
\text { mencantumkan } \\
\text { sumber, } \\
\text { dilengkapi } \\
\text { keterangan yang } \\
\text { diperlukan }\end{array}$ \\
\hline Bahasa & $\begin{array}{c}\text { Terlalu } \\
\text { ilmiah (sulit } \\
\text { dipahami } \\
\text { siswa SD) }\end{array}$ & $\begin{array}{c}\text { Bahasa } \\
\text { disederhanakan }\end{array}$ & $\begin{array}{c}\text { memuat contoh } \\
\text { untuk } \\
\text { memperjelas }\end{array}$ \\
\hline
\end{tabular}

Menurut paham konstruktivisme tentang bagaimana hasil belajar diperoleh siswa, disebutkan bahwa pengetahuan dibangun oleh siswa melalui bermacammacam aktivitas. Untuk mencapai hasil belajar itu diperlukan kelengkapan-kelengkapan yang digunakan dalam proses belajar, seperti antara lain sumber belajar.
Sumber belajar penting yang harus selalu hadir dalam kegiatan pembelajaran adalah buku ajar, yang dipergunakan dengan cara membacanya, memahami dan menerapkannya. Bahan ajar berbasis konteks yang disusun sesungguhnya merupakan turunan dari pendekatan CTL (Contextual Teaching and Learning). Banyak penelitian mengenai CTL yang mengungkapkan keunggulan pendekatan ini, baik terhadap hasil belajar, maupun terhadap aspek kognitif lain seperti kemampuan berfikir tingkat tinggi bahkan terhadap sikap dan perilaku (Ditjen Dikdasmen, 2003). CTL membantu guru untuk mengaitkan materi yang dipelajari dengan dunia siswa atau situasi/kondisi dimana pembelajaran itu terjadi.

Filosofi kontruktivisme merupakan salah satu landasan teoritik pembelajaran kontekstual. Secara operasional pembelajaran kontekstual merupakan implementasi kontruktivisme. Hal ini disebabkan pembelarannya yang berbasis scaffolding. Secara operasional dalam pembelajaran sehari-hari konsep scaffolding berupa pemberian bantuan yang terstruktur kepada para siswa agar belajar bertanggungjawab atas dasar keputusannya sendiri dengan kata lain siswa masih diberikan bantuan namun sedikit-sedikit bantuan tersebut dikurangi.

Knapp and schell (200I) mengemukakan bahwa belajar dalam konteks yang banyak memberikan siswa pengalaman menggunakan apa yang dipelajari mengidentifikasi dan menyelesaikan permasalahan pada konteks-konteks yang baru. Sekolah tidak perlu banyak mengajarkan terlalu banyak konten tetapi mengajarkan sedikit konten dengan cara yang baik. Dengan berfokus pada konten yang lebih sedikit, guru akan menyampaikan ide secara bertahap dalam berbagai konteks memberikan pendalaman dan penguatan materi bagi siswanya. Dengan demikian siswa memiliki wawasan yang kaya dan mendalam daripada hanya memperoleh bahasan yang banyak tetapi dangkal ( $\mathrm{Tjalla}$, 2009).

Melatihkan kemampuan kreatif juga dimunculkan dalam bahan ajar. Kreativitas perlu dikembangkan pada diri siswa karena melalui kreativitas seseorang dapat mengaktualisasi dirinya (self actualization), memberikan kepuasan tersendiri (satisfaction), dan melalui kreativitas akan mampu meningkatkan kualitas hidup seseorang (Safilu, dalam Arwita 2013). Bahan ajar yang disusun memfasilitasi siswa untuk melakukan kegiatan kreatif, seperti menggambarkan siklus hujan dengan menggunakan bahan-bahan yang seadanya, menuliskan poster untuk melindungi hewan, memberikan usulan dalam bentuk paragraf bagaimana cara untuk menjaga kesehatan gigi.

Kompetensi tugas perkembangan itu merupakan potensi yang dapat dipupuk agar dikuasainya literasi sains oleh siswa pada usia 6 hingga I2 tahun. Penguasaan literasi sains tersebut diperoleh melalui pembelajaran sains di sekolah dasar yang dapat dilakukan secara bertahap dan konsisten. 
Usia anak masa sekolah pada tingkat Sekolah Dasar berkisar antara usia 6 tahun hingga 12 tahun. Menurut teori perkembangan, pada usia tersebut mereka sedang dalam berada dalam kondisi tugas perkembangan. Havighurst (Yusuf, 2003) merinci tugas-tugas perkembangan tersebut. Pertama, belajar memperoleh keterampilan fisik untuk melakukan permainan. Kedua, belajar membentuk sikap yang sehat terhadap dirinya sebagai makhluk hidup biologis. Ketiga, belajar bergaul dengan teman-teman sebaya, Keempat, belajar memainkan perannya sesuai dengan jender. Kelima, belajar keterampilan dasar dalam membaca, menulis dan berhitung. Keenam, belajar mengembangkan konsep sehari-hari, Ketujuh, mengembangkan kata hati. Kedelapan, belajar memperoleh kebebasan yang bersifat pribadi, kesembilan, mengembangkan sikap yang positif terhadap kelompok-kelompok sosial dan lembagalembaga.

Tanggapan guru yang diperoleh dari hasil wawancara terhadap 4 orang guru menunjukkan bahwa guru berpendapat bahwa bahan ajar menarik dalam segi tampilan (75\%), bahan ajar sederhana namun mampu membelajarkan IPA di SD secara bermakna (I00\%), Guru tertarik untuk membuat bahan ajar seperti ini (50\%), dan bahan ajar mampu melatihkan literasi sains (75\%). Berdasarkan hasil yang diperoleh dapat diambil kesimpulan bahwa guru memberikan respon positif terhadap bahan ajar berbasis konteks dan kreativitas yang dikembangkan.

Semua guru dan semua fihak yang berkontribusi baik sebagai pelaksana pengajaran maupun yang memiliki pengaruh terhadap pengajaran sains di tingkat sekolah dasar harus memiliki tanggung jawab terhadap pencapaian literasi sains oleh para siswanya. Guru hendaknya mau melaksanakan inovasi pendidikan agar terjadi pembaharuan dengan mengangkat isu atau masalah di masyarakat ke dalam kelas.

\section{Simpulan}

Telah dihasilkan bahan ajar berbasis konteks dan kreativitas untuk melatihkan literasi sains yang merupakan hasil akhir dari proses inovasi yang dikembangkan melalui riset pengembangan. Bahan ajar telah memenuhi aspek ajar dari penilaian ahli, peer reviewer, dan uji coba terhadap siswa. Diperoleh juga tanggapan dari guru yang pada umumnya memberikan respon positif terhadap bahan ajar yang dihasilkan. Diharapkan bahan ajar yang dikembangkan dapat menjadi sumber belajar bagi siswa di kelas 4 dan 5 SD untuk melatihkan literasi sains.

\section{Daftar Pustaka}

Aikenhead, G (2006). Science Education for Everyday Life. New York: Teacher's College Press.

Anwar, S (2010). Pengolahan Bahan Ajar. Bandung. Program Pasca Sarjana Universitas Pendidikan Indonesia.
Arwita Widya (2013). Pemberdayaan Keterampilan Berfikir Kreatif Ilmiah Siswa melalui pembelajaran Bioteknologi Berbasis Scientific, Technology, and information Literacy. Tersedia https://www.academia.edu/4535288/. (I5 Maret 2015)

Barker, V., \& Millar, R. (I999). Students reasoning about basic chemical reactions: What changes occur during a context-based post-I6 chemistry course? International Journal Science Education, 2I(6), 645-665.

Bennett, J., \& Lubben, F. \& Hogarth, S. (2006). Bringing science to life: A synthesis of the research evidence on the effects of context-based and sts approaches to science teaching. Science Education, 9I(3), 347370 .

Depdiknas. (2006). Pedoman Memilih dan Menyusun Bahan Ajar. Jakarta: Depdiknas.

Dirjen Dikdasmen (2003). Pembelajaran Kontekstual. Proyek peningkatan Mutu SLTP Jakarta.

Holbrook, J. (2005). Making Chemistry Teaching Relevant.Chemical Education International, 6 (I), I-I2.

Knap N. F dan J. W Schell. (200I). Pshychological and Sosiological Foundations of CTL. Paper presented at the 200I annual meeting of the American Education Research Association Seatle WA.

Köse, E., \& Tosun, F. (201I). Effect of context based learning in students achievement about nervous system. Journal of Turkish Science Education, 8(2), 9I-106.

Norris, S. P., \& Phillips, L. M. (2003). How literacy in its fundamental sense is central to scientific literacy. Science Education, 87, 224-240.

OECD (2009). PISA 2009 Assessment Framework. Key Competencies in Reading, Mathematics.and Science.Organisation for Economic Co-operation \& Development \&Unesco Institute for Statistics.

OECD (2009). PISA 2009 Result.Executive Summary. Organisation for Economic Co-operation \& Development \&Unesco Institute for Statistics.

OECD (2013).PISA 2009 Result.Executive Summary. Organisation for Economic Co-operation \& Development \&Unesco Institute for Statistics.

Phearson, P.T.; Pollack, G.R.; and Sable, J.E. 2008. Increasing scientific literacy in undergraduate education: A case study from "frontiers of science" at Columbia University.

Ramsden, M. J. (1997). How does a context-based approach influence understanding of key chemical ideas at I6+?.International Journal of Science Education, I9(6), 697-7I0.

Rustaman, N. (2004). Literasi Sains Anak Indonesia 2000, 2003. [Online]: Tersedia: literasi sains $\% 20$ anak $\% 20$ Indonesia $\% 20 \quad$ (5 Jan 2015) 
JURNAL BIOEDUKATIKA Vol. 4 No. 2 Tahun 2016 p-ISSN: 2338-6630 e-ISSN: 254I-5646 | Halaman

Sukmadinata, Nana Syaodih. (2005). Metode Penelitian Pendidikan. Bandung: Rosdakarya

Suratno, Tatang (2009). Pengembangan Kreativitas Siswa dalam Pembelajaran Sains di Sekolah Dasar.

Tjalla, A (2009). Potret Mutu PendidikanIndonesia ditinjau dari Hasil-Hasil Studi Internasional. [Online]. http://pustaka.ut.ac.id/pdfartikel/TIG60I.pdf (II Agustus 2016)

Toharudin, U. (20II). Membangun Literasi Sains Peserta Didik. Bandung: Humaniora.

Yusuf (2003). Literasi Peserta Didik Indonesia. Laporan PISA 2003. Pusat Penilaian Pendidikan Nasional. 